\title{
DAJE LI VAM VJERA ZDRAVLJE? ZAKLJUČCI IZ EMPIRIJSKE RELIGIJSKE PSIHOLOGIJE
}

\author{
Johannes Panhofer
}

Sveučilište u Innsbrucku

UDK: 2-423.79:159.938.363.6

Institut za praktičnu teologiju

johannes.panhofer@uibk.ac.at.

https://doi.org/10.34075/cs.56.3.2
Pregledni znanstveni rad
Rad zaprimljen 7/2021.

\section{Sažetak}

Vodeći brigu o sebi želimo razumjeti svoje vlastite potrebe s ciljem da održavamo svoje fizičko i psihičko zdravlje. O tome jesu li vjera $i$ duhounost izvori (mentalnog) zdravlja i osobne dobrobiti ili prije rizik, vode se krajnje kontroverzne rasprave. Spor nastaje između iskustava pojedinaca s jedne strane $i$ ideoloških rovovskih ratova s druge. Ovaj rad postavlja raspravu na „objektivnu“ osnovu predstavljajući zaključke utemeljene na dokazima iz različitih studija. Iz toga se vidi da se ponovno otkrivaju iscjeljujuće moći vjere i duhovnosti. Ipak, neophodna je savjesnost $i$ potrebni su određeni kriteriji kako bi vjera mogla razviti svoju iscjeljujuću moć. Dakle, studije utemeljene na dokazima pokazuju: religioznost u različitim slučajevima i psihičkim situacijama nije ista! Moramo otkriti kada, gdje i zašto religioznost ima konstruktivan ili destruktivan učinak.

Ključne riječi: religijska psihologija, mentalno zdravlje, utočište, ljekoviti čimbenici, rizični čimbenici

\section{UvoD}

Oduvijek postoji prepirka o pitanju je li religija, odnosno duhovnost izvor ili pak prepreka za psihičko zdravlje i osobno dobrostanje čovjeka. Vrlo je sporno podupire li religija skrb o samome sebi ili je pak onemogućuje. Rasprava o štetnim, odnosno blagotvornim učincima religije često je spekulativna, pa čak i ideološki obojena, te dolazi do instrumentalizacije od strane raznih skupina. Cesto je rasprava obilježena jednostranim, individualnim iskustvima. Uz oslobađajuće i blagotvorne doživljaje postoje očito i učinci religioznosti koji čovjeka skuče i čine bolesnim. Što je, dakle, točno? Tko je u pravu? Možemo li reći nešto „objektivno“ o ovoj temi? 
Ovaj prilog želi - mimo osobnih želja i spekulativnoga govora - utemeljiti raspravu na empirijskim, tj. provjerljivim, spoznajama. Danas postoje opširne studije o odnosu religioznosti i psihičkoga zdravlja, pa one tvore dobru podlogu za spoznaje koje se temelje na činjenicama. One s jedne strane iznova otkrivaju iscjeliteljsku snagu religije i duhovnosti, a s druge strane upućuju na oprez prema mogućim opasnostima. U svakom su slučaju nužni kriteriji kako bi religija mogla razviti svoju blagotvornu snagu.

Tema ovoga priloga u izravnoj je svezi sa simpozijem. Skrb za samoga sebe, briga za samoga sebe, njega samoga sebe - kako god preveli pojam self-care - njihova je svrha ojačati vlastito tjelesno, psihičko i mentalno dobrostanje, odnosno ponovno ga uspostaviti ako je narušeno ili izgubljeno. Mogli bismo reći: riječ je o zdravlju u tjelesnom, psihičkom i duhovnom smislu.

Na primjeru ovoga teksta želim pokazati koji vid želim naglasiti u surječju religije, duševnoga zdravlja i skrbi za samoga sebe, a to je - samozapažanje i ljubav prema sebi samome.

Početkom šezdesetih godina prošloga stoljeća, za vrijeme Drugoga vatikanskog sabora, poznati psihoanalitičar i uvjereni katolik Görres sastavio je prilog o (mogućim) patološkim stranama kršćanstva za Priručnik pastoralne teologije koji je izdao Karl Rahner; tim je tekstom izazvao mnogo pozornosti. U svome prilogu dijagnosticira manjkavu spoznaju samoga sebe i tabuiziranje potisnutoga zapažanja unutarnjih težnji među kršćanima u katolicističkom miljeu ${ }^{1}$ : „Dolazi do plašljive obrane od profinjenijih duševnih spontanih težnji. Na pomalo stravičnom području nekontroliranih zapažanja, neracionalnih osjećaja, slobodnih intuicija, fantazija i asocijacija kao da se nalazi opasna klica proizvoljnosti i pobune, klica sumnje, samovoljnih pogleda, zamišljenosti nad problemima i nekonformističkih ideja; osim toga, kao da se tu stalno nazire buntovna osjetilnost." Görres smatra da se katolici ponašaju uštogljeno i plašljivo pred nepristranim zapažanjem samoga sebe te se opiru zapažanju neželjenih težnji kao što su neprijateljstvo, zavist i nelagoda u odnosu prema Bogu kojeg doživljavaju kao nepravednog. „Oni ne žele i ne smiju znati što se u njima zbilja događa. ... (No) Svako otuđenje od samoga sebe, svako odbijanje kontakta s nutrinom također remeti međuljudske kontakte."2

1 Görres rabi pojam „katolicistički milje“ u smislu pretjerane, jednostrane i skučene reprezentacije rimokatoličkoga svjetonazora i vrijednosnog sustava u predodžbama vjernika na štetu individualnih osjećaja koji se protive tim vrjednotama.

2 Albert Görres, Pathologie des katholischen Christentums, K. Rahner - F.X. Arnold (izd.), Handbuch der Pastoraltheologie. Praktische Theologie der Kirche in ihrer Gegenwart, II/ 1, München, 1966., 277-343, 304. 
U zaključku ću se vratiti na ovo iskrivljeno zapažanje - koje Görres doduše predstavlja na vrlo karikiran način - jer mi se čini da je to jedna od odlučujućih poveznica teme skrbi za samoga sebe i rezultata empirijske religijske pedagogije.

Započinjem s nekoliko napomena o povijesti empirijske religijske psihologije jer su zanimljive ne toliko s povijesnoga gledišta koliko zbog samoga sadržaja (1). Zatim slijedi kratak pregled klasičnih polja empirijskog istraživanja (2) te izabrane teme u svezi s religijom i zdravljem (3). U zaključku povezat ću rezultate istraživanja o iscjeliteljskom vidu religije s temom skrbi za samoga sebe (4).

\section{ISKRICE IZ POVIJESTI EMPIRIJSKOG ISTRAŽIVANJA RELIGIJE}

U svezi s prikazom nekih rezultata empirijske religijske psihologije svakako treba imati na umu sljedeće: u ovom ograničenom okviru možemo pružiti samo mali uvid u tu složenu i razgranatu temu. Pojedini su aspekti produbljeni u navedenoj literaturi.

Ponajprije, u shvaćanju mnogih religija bez ikakve su dvojbe povezani vjersko spasenje i fizičko, odnosno psihičko iscjeljenje/ zdravlje. Na području profesionalnoga zdravstva pak, osobito u psihijatrijsko-psihoterapeutskom shvaćanju, takav stav tradicionalno izaziva suzdržanost. Zaista su prva istraživanja o povezanosti religioznosti i (psihičkoga) zdravlja proturječna. Studije provedene do kraja šezdesetih godina potvrđuju nejasnu ili čak pojačanu poveznicu plašljivosti, sklonosti dependenciji i depresivnosti, s jedne strane, te autoritarizma i sklonosti predrasudama, s druge strane. ${ }^{3}$ Tek od osamdesetih godina mogu se ustanoviti blagi pozitivni učinci religioznosti na psihičko i fizičko zdravlje, primjerice bolje psihičko zdravlje, manje stresa, veće zadovoljstvo sa životom, manja depresivnost, veće zadovoljstvo u braku i obitelji te duži život. Kako se to slaže jedno s drugim te kako to protumačiti?

Želim istaknuti tri vida koja su važna za tumačenje rezultata. Pogledajmo najprije stanje istraživanja. Zadugo smo samo iz SAD-a raspolagali opširnim studijama o povezanosti religioznosti i zdravlja. Pri tumačenju tih rezultata treba imati na umu da se ondje religija shvaća na drugačiji način nego u Europi te da ima znatno veće društveno i osobno značenje. Primjerice, 95 \% Amerikanaca čvr-

3 Constantin Klein, Cornelia Albani, Religiosität und psychische Gesundheit. Eine Übersicht über Befunde, Erklärungsansätze und Konsequenzen für die klinische Praxis, Psychiat Prax 2007; 34: e2-e12, e4. 
sto vjeruje u Boga ili neko više biće, 66 \% njih pripada nekoj vjerskoj zajednici, 44 \% odlaze makar jednom tjedno na bogoslužje. ${ }^{4}$ Usporedbe radi: U Njemačkoj tjedni je dolazak na bogoslužje $15 \%$ u Katoličkoj Crkvi, a samo $4 \%$ u protestantskoj. $55 \%$ Amerikanaca smatra da je religija vrlo važna u njihovu životu, dok samo $20 \%$ Nijemaca zastupa takav stav. S obzirom na religioznost na svjetskoj razini, Europa je zaseban slučaj; pri tome nekadašnji socijalistički krajevi dosežu osobito ekstremne postotke: 54 \% istočnih Nijemaca odbija bilo kakvu predodžbu o Bogu, što je jedinstven slučaj u čitavome svijetu! Sve te različite društvene okolnosti moramo uzeti u obzir pri prosudbi istraživanja iz SAD-a.

U tom je surječju znakovita i sljedeća dimenzija: u Europi nailazimo na opći stav koji je izrazito kritičan prema religiji, dakako, uz mnoge nacionalne i regionalne razlike. Mnogo je razloga za to, u koje pak sada ne želim ulaziti. Čini se da su prosvjetiteljstvo te osobito Marx, Feuerbach i Freud izvršili vrlo učinkovit i dugotrajan utjecaj. Za mnoge je religija nezreo, djetinjast oblik života, ili - kako se Freud izrazio - „kolektivna prisilna neuroza“, odnosno iluzija, tj. „regresivna želja za nadmoćnim ocem koji te štiti“. ${ }^{5}$

Navedimo drugi ključni aspekt koji je donio važne spoznaje za daljnji razvoj istraživanja o religiji. Američki učenjak Allport, koji je istraživao predrasude, ušao je u trag spomenutim proturječnim rezultatima te je kod ispitanika otkrio što je uzrok. ${ }^{6}$ Naime, ovisno o vrsti religioznosti dolazi se do različitih rezultata. Allport je kao prvi razlikovao nešto što je nama danas dobro poznato - a to su intrinzična i ekstrinzična religioznost. Dok intrinzična religioznost proizlazi iz unutarnjeg uvjerenja i povjerljivog odnosa prema Bogu radi samoga odnosa, ekstrinzična je religioznost više obilježena naučenom, nedostatno reflektiranom vjerom i slabim osobnim odnosom prema Bogu te je također jače povezna s iščekivanjima neke koristi, kao što je, primjerice, socijalni ugled. Tako religija postaje „ultimativno životno osiguranje“. To razlikovanje vrsta religioznosti bitno je utjecalo na kasnija istraživanja te je pridonijelo daljnjoj diferencijaciji oblika i kakvoće religioznosti. Dok su se prijašnje studije služile količinskim kriterijima, kao što su broj dolazaka u crkvu, učestalost molitve i susreta zajednice itd., sada se pokušavalo odrediti unu-

$4 \quad$ Usp. Constantin Klein, Cornelia Albani, Religiosität und psychische Gesundheit. Eine Übersicht über Befunde, Erklärungsansätze und Konsequenzen für die klinische Praxis, Psychiat Prax 2007; 34: e2-e12, e3.

5 Bernhard Grom, Religionspsychologie, München, ${ }^{32007 ., ~ 38-48 . ~}$

6 Bernhard Grom, Religionspsychologie, München, ${ }^{32007 ., ~ 23-26 . ~}$ 
tarnju kakvoću vjere. Od tada je moguće jasnije i točnije istraživati učinak određenih oblika religioznosti. Nastali su mnogovrsni, višedimenzionalni pristupi i pogledi na religioznost. ${ }^{7}$

Naposljetku, postoji i treći događaj koji je bitno izmijenio gledište na religioznost. Stari, klasični pogled, koji je bio pod snažnim utjecajem psihoanalize, samo je tematizirao čimbenike koje izazivaju bolest. Nije to moglo ni biti drugačije: istražujući samo bolesne ljude (koji podliježu prisilama, depresiji, shizofreniji itd.), moglo se naići samo na čimbenike koji pogoduju bolesti.

Odlučujući se zaokret dogodio kada su istraživači drugačije usmjerili svoja pitanja te nisu više (samo) pitali što ljude čini bolesnima, nego što ih održava zdravima, odnosno što ih čini zdravima. Upravo u surječju stresa i većeg rizika za obolijevanje trebali su naći odgovor na pitanje zašto neki ostaju zdravima i agilnima unatoč velikom opterećenju, tako da čak i sazrijevaju svladavajući poteškoće, dok drugi padaju pod takvim teretom? Odjednom su otkrili religioznost kao izvor koji daje snagu i iscjeljuje. Povijest istraživanja maknula se od gledišta koje je bilo usmjereno na nedostatke i patologije, a promatrala je što potiče razvoj i zdravlje (salutogeneza).

Ovim je pozitivnim gledištem početkom devedesetih godina i u Europi započelo (ponovno) proučavanje religijske psihologije, koje je dugo bilo zanemareno. Zemlje kao što su Belgija, Nizozemska i Švicarska prednjačile su u tome, dok ih je njemačko govorno područje slijedilo sa zakašnjenjem. Zanimanje za religioznost kao resurs krenulo je najprije osobito iz teologije, a u proteklih 20 godina stiglo je i na područje kliničke psihologije.

\section{EGZEMPLARNA POLJA EMPIRIJSKE PSIHOLOGIJE RELIGIJE}

\subsection{Psihologija razvoja i vjerske kognicije ${ }^{8}$}

S obzirom da među čitateljstvom ima tolikih stručnjaka i stručnjakinja iz pedagogije, dovoljno je samo kratko reći: Teorije Piagetove tradicije i istraživanja s područja psihologije razvoja o vjerskim kognicijama tvore od samoga početka težište istraživanja empirijske

7 Bernhard Grom, Religionspsychologie, München, ${ }^{32007 ., ~ 26-28 . ~}$

8 U svezi s ovdje predstavljenim egzemplarnim podtemama vidi: Constantin Klein - Heinz Streib, Religionspsychologie im deutschsprachigen Raum. Ein Überblick, Praktische Theologie, 46 (2011.) 4, 197-203. 
psihologije religije te su temeljne za religijsku pedagogiju. Kao klasične modele spomenut ću Fowlerov i Oserov. ${ }^{9}$ Vjeronauk iz teološke perspektive bio je omiljeno područje empirijskog istraživanja, $u$ kojem su osobito prednjačili teolozi i teologinje.

\subsection{Konverzija i dekonverzija u surječju fundamentalističkih zajednica}

Drugačije je stanje empirijskih istraživanja o životnim zaokretima u vjerskim životopisima: područje konverzije [tj. obraćenja: nap. prev.] spada u klasična područja religijske psihologije od samih početaka do danas (npr. W. James). U Njemačkoj tom se tematikom bavi radna skupina religijske psihologije u Bad Kreuznachu. ${ }^{10}$

\subsection{Religioznost, sklonost predrasudama i ksenofobija}

U klasična pitanja religijske psihologije također spada poveznica religijskih uvjerenja i predrasuda, odnosno ksenofobije. Empirijski nalazi nažalost potvrđuju „da općenito veća religioznost nosi sa sobom pojačanu ksenofobiju, antisemitske tendencije, homofobiju i omalovažavanje vjerskih ili političkih neistomišljenika“" ${ }^{11}$. Zapravo, homofobija, podcjenjivanje žena i rasistički stavovi postoje u skupni 'pretežito religioznih', ali ne u skupini 'izrazito religioznih'. Drugim riječima: Čini se da je površna religioznost sklonija predrasudama od pounutarnjene religioznosti. Taj nas rezultat podsjeća na razlikovanje raznih oblika religioznosti prema Allportu. Te su razlike postale vrlo očite upravo proteklih godina u velikim migracijskim gibanjima, kada određene vjerske skupine nastupaju protiv migranata. Međutim, susret $s$ onim što je strano i drugačije može biti iskustvo kreativnog izazova i velikih vrijednosti, primjerice u slučaju izrazito religioznih osoba.

$9 \quad$ Fritz Oser, Wieviel Religion braucht der Mensch? Erziehung und Entwicklung zur religiösen Autonomie, Gütersloh, ${ }^{3}$ 1993.; Friedrich Schweitzer, Lebensgeschichte und Religion. Religiöse Entwicklung und Erziehung im Kindes- und Jugendalter, Gütersloh, ${ }^{7} 2010$.

10 Usp. Sussan Namini, Selbst gewählte Mitgliedschaft in Neuen Religiösen Bewegungen - eine Frage der Passung? Empirische Befunde und kritische Überlegungen, Marburg, 2009.

11 Constantin Klein - Heinz Streib, Religionspsychologie im deutschsprachigen Raum. Ein Überblick, Praktische Theologie, 46 (2011.) 4, 197-203, 200. 


\section{RELIGIOZNOST I ZDRAVLJE}

Spomenuta područja već sadrže dimenzije koje se tiču (psihičkoga) zdravlja: zdrav razvoj, blagotvorne kognitivne slike o Bogu, razlikovanje skrupuloznih, zamišljenih ili zbiljskih osjećaja krivnje, itd. ...

Složeno područje istraživanja poveznice religioznosti i psihičkoga, odnosno tjelesnog zdravlja možemo podijeliti na četiri potpodručja: ${ }^{12}$

Religija je prije svega čimbenik salutogeneze i rezilijencije. Vjera ovdje ima ulogu psihičke otporne snage protiv stresa koja jača „duševni imunosni sustav“. Drugu dimenziju možemo objasniti pomoću teorije vezivanja: Rani obrasci navezivanja (i unutarnjih obveza) prenose se na vjerske likove: osjećaj prihvaćenosti te utjeha i oslonac. Treća nam se dimenzija otkriva u takozvanom istraživanju o suladavanju problema ${ }^{13}$, a to je snaga kojom religija snaži i ponovno uspravlja čovjeka. Odlučujući su parametri kognitivne procjene i individualne strategije svladavanja. Konačno, imamo veliko područje istraživanja meditacije. Učinak meditacije i molitve pokazuje pozitivne rezultate u slučaju kroničnih bolesti i strahova, depresija, borderline poremećaja, rehabilitacije od droge i slično.

Nekoliko iskrica iz psihološko-religijskih studija: U sklopu medicinske studije na Sveučilištu Harvard Benson je ustanovio da redovita molitva i meditacija rezultiraju znatnom opuštenosti. ${ }^{14}$ To pogoduje liječenju visokoga krvnog tlaka, poremećaja srčanog ritma, kroničnih boli, lakših do srednjih depresija i drugih bolesti.

Pri tome dakako postoje različiti molitveni stilovi, to jest upravo tri, koji sežu od pasivnoga iščekivanja do magijskog optimizma. ${ }^{15}$ Prvi je self-directing style, koji ustraje na vlastitoj odgovornosti u rješavanju poteškoća, prema načelu: „Ako sam u problemima, onda sam odlučujem koje ću im značenje pridati - bez Božje pomoći.“ Zatim je to deferring style, prema kojemu će se Bog za sve pobrinuti te nije potrebno mnogo sudjelovanja s čovjekove strane: „Ne razmišljam o rješenjima za svoj problem jer će se Bog pobrinuti za rješenje." Naposljetku postoji collaborative style, u kojem vidim vlastitu

12 Usp. radi općega pregleda: Harald George Koenig - Micheal E. McCullough David B. Larson, Handbook of Religion and Health, New York, 2001.

13 njem.: Bewältigungsforschung (nap. prev.)

14 Herbert Benson, Heilung durch Glauben. Selbstheilung in der neuen Medizin, München, 1997.

15 Kenneth I. Pargament i dr., Religion and the problem-solving process: three styles of coping. Journal for the Scientific Study of Religion, 27, 90-104; Bernhard Grom, Religionspsychologie, München, ${ }^{3} 2007 .$, 83-84. 
odgovornost, ali u dijalogu s Bogom i s Njegovom pomoći: „Gospodin djeluje sa mnom da mi pomogne dosjetiti se različitih načina kako riješiti problem.“ Taj je treći stil najučinkovitiji.

Druge studije koje su istraživale slična pitanja potvrđuju spomenute rezultate te ih produbljuju. Matthewsova studija će primjerice ustvriti da su pacijenti koji vjeruju i koji se mole u manjoj mjeri nepokretni nakon operacije, potrebno im je manje sredstava protiv bolova te se njihov krvni tlak brže spušta. ${ }^{16}$

Posebno mjesto zauzima Snowdonova takozvana studija o redovnicama (Nun Study). Ta jedinstvena longitudinalna studija koja obuhvaća 678 redovnica franjevki iz SAD-a uspoređuje zdravstveno stanje redovnica i njihove pojedine vjerske stilove. ${ }^{17}$ Ta se usporedba temelji na životnim opisima časnih sestara, počevši od razdoblja novicijata prije polaganja zavjeta (1931. - 1943.) do njihove visoke starosti. Sestre su dale pristanak za opetovana fiziološka i psihološka istraživanja. Analiza sadržaja autobiografskih tekstova pokazala je znatne razlike s obzirom na emocionalni izričaj i dobrostanje, s ovim rezultatom: Što su jače bile zastupljene pozitivne emocije poput zahvalnosti, osjećaja zaštićenosti, radosti, smirenosti, to je bolje bilo zdravstveno stanje.

Takozvana Hamburška studija o slici Boga u kojoj su Schwab i Petersen ${ }^{18}$ ispitali 115 žena i 91 muškarca o povezanosti slike o Bogu i zadovoljstva sa životom/zdravljem, pokazala je sljedeće: Što su sudionice i sudionici zauzetiji u vjerskom pogledu, to manje pokazuju neurotične karakteristike. Osobe koje smatraju da Bog ljubi i pomaže, manje se osjećaju osamljenima te su u većoj mjeri zadovoljne. Nije nikakvo iznenađenje da slika Boga kao sudca koji kažnjava ima suprotan učinak, a to su osjećaji osamljenosti i nezadovoljstva.

Nemoguće je ovdje navesti sva istraživanja jer ih ima na tisuće. To je, međutim, za nas učinio Koenig sa suradnicama i suradnicima analizirajući oko 1200 studija. ${ }^{19}$ Sve upućuje na iste rezultate: reli-

16 Dale A. Matthews, Glaube macht gesund. Spiritualität und Medizin, Freiburg, 2000.

17 David Snowdon, Lieber alt und gesund. Dem Altern seinen Schrecken nehmen, München, 2001.

18 Reinhold Schwab - Kay U. Petersen, Religiousness: Its relation to loneliness, neuroticism and subjective well-being. Journal for the Scientific Study of Religion, 29 (1990.) 3, 335-345.

19 Harald G. Koenig - Micheal E. McCullough - David B. Larson, Handbook of Religion and Health, New York 2001; Harald G. Koenig, Is Religion good for Your Health?. The Effects of Religion on Physical and Mental Health, New York, 1997. 
gioznost je popraćena nižim krvnim tlakom, manjom zlouporabom supstancija, manjim brojem srčanih bolesti, manjom stopom suicida, učinkovitijom strategijom svladavanja problema i većim dobrostanjem, odnosno životnim zadovoljstvom. Religioznost se slaže s boljim psihičkim zdravljem, manjim stresom, većim zadovoljstvom sa životom i samoostvarivanjem, manjom depresivnošću, većim zadovoljstvom u partnerstvu te dužim životom.

Sada već postoje poprilično dobre studije o učinku religioznosti na određeni tijek bolesti, primjerice u slučaju depresije, shizofrenije, zlouporabe supstancija, anksioznih poremećaja i prisilnih poremećaja. Ovdje ću spomenuti kao reprezentativnu za mnoge druge studije rad Human-Friedricha Unterrainera, koji je proučavao značenje religioznosti za ljude oboljele od depresije i ovisnosti. ${ }^{20}$

Nakon svih pozitivnih pokazatelja postavlja se, dakako, pitanje na koji način i po čemu religioznost djeluje. Pri tome se uvijek pokazuje pet razina koje razvijaju blagotvorne snage: ${ }^{21}$ Religija ponajprije pruža emocionalno rasterećenje na način da događaje, životne tragedije i slično uklapa u načelno smislenu sliku svijeta dajući im tako neki smisao. Ona pri tome pruža i moralnu orijentaciju te pomaže u stjecanju etički odgovornog načina života (protiv zlouporabe supstancija i nesputane agresije). Ona pruža socijalnu potporu po uključivanju u zajednicu te time i onu konkretnu pomoć koja je potrebna u svakodnevici. Ona daruje mogućnost ponovne, odnosno nove kognitivne procjene po vjeri u djelovanje više moći u situacijama besmisla. Religija u konačnici učvršćuje mentalne strategije svladavanja problema, kao što je pružanje utjehe, nade i smirenosti u bezizlaznim situacijama.

\section{Sažetak}

Premda ostaje još mnogo neriješenih pitanja o odnosu zdravlja i religije, možemo na pojednostavnjen način sažeto reći: Religija ponajprije nije ni dobra ni loša, nego - religija i duhovnost mogu biti ili dio problema ili dio rješenja. I dalje postoje učinci nezrele i opterećene religioznosti u kojoj se opravdavaju mržnja, agresija, predrasude i iskazivanje moći. Strah i osjećaj krivnje mogu se pojačati te

20 Human-Friedrich Unterrainer, Spiritualität und psychische Gesundheit. Glaube als Ressource in der Krankheitsverarbeitung, Saarbrücken, 2007.

21 Michael Utsch, Religiöse Fragen in der Psychotherapie. Psychologische Zugänge zu Religiosität und Spiritualität, Stuttgart, 2005., 184. 
pretjerane religiozne aktivnosti mogu poslužiti za zaobilaženje predstojećih međuljudskih sukoba (tzv. duhovni by-passing). ${ }^{22}$

Stoga vrijedi: Religija nije jednako religiji. Potrebno je dobro se priupitati: Koja je ovo religija i koju funkciju ima za psihu? „...Stoga, odlučujuće pitanje nije jesu li religija i duhovnost dobre ili loše, nego kada, kako i zašto poprimaju konstruktivne ili destruktivne oblike." ${ }^{23}$ Uvijek se postavlja pitanje na kakvom su psihološkom tlu „posijane“ slike o Bogu i vjeri te kako ondje djeluju.

Ipak se sveukupno u studijama može zaista prepoznati utemeljena, blago pozitivna povezanost religioznosti i zdravlja. No „blago pozitivne korelacije same po sebi upućuju na djelovanje s mnogo čimbenika u kojem ne djeluje samo jedan jedini uzrok - koji pomalo neodređeno nazivamo, religioznost‘. ... Ipak, taj djelatni čimbenik posjeduje zanosan potencijal." 24

Sljedeća nam pitanja mogu pomoći u razlučivanju: Dovodi li vjera do veće slobode? Pomaže li u nošenju s bolesti i opterećenjima? Dovodi li vjera do većega uključivanja u socijalni život? Omogućuje li vjera veću fizičku i psihičku uravnoteženost? Potiče li vjera veću zahvalnost, zadovoljstvo i sreću?

Dopustite mi na kraju još jednu kritičnu napomenu uz empirijske studije. Koliko god te studije bile informativne i korisne, ne smijemo ipak zaboraviti: Psihološki pogled na vjeru je funkcionalan, tj. religija se instrumentalizira za zdravlje te ju se svodi na mjerljivu funkciju. Teološki pak pogled usmjeren je na spasenje, a ne na iscjeljenje. „Ne uzima se u obzir da [religija, osobito kršćanska vjera] može pronaći smisao i u nečemu što je neizlječivo. “25 Onaj prvi pogled može osloboditi osobu primjerice od osjećaja krivnje, ali ne daje odgovor kako će se osloboditi krivnje kao takve. Vrijednost vjere

22 Ovaj je pojam skovao američki psihoterapeut i budistički učitelj John Welwood; odnosi se na duhovno zaobilaženje, odnosno duhovno izbjegavanje neriješenih emocionalnih problema, osobnih rana i neodređenih razvojnih koraka, upravo posredstvom duhovnih ideja i slika. Ovdje duhovnost služi izbjegavanju!

23 Franz Reiser, Menschen mehr gerecht werden. Zur Religiosität bzw. Spiritualität von Patientinnen und Patienten in Psychiatrie und Psychotherapie (Studien zur Theologie und Praxis der Caritas und Sozialen Pastoral), Würzburg, 2018., 161.

24 Klaus Baumann, Religiöser Glaube, persönliche Spiritualität und Gesundheit. Überlegungen und Fragen im interdisziplinären Feld von Theologie und Religionswissenschaft, Medizin und Psychotherapie. Zeitschrift für medizinische Ethik 55 (2), 131-144, 137.

25 Isidor Baumgartner - Karl Heinz Ladenhauf, Von der psychologischen Notwendigkeit der Religion. Zur gesundheitsfördernden Kraft der Religion, I. Baumgartner, C. Friesl \& A. Máté-Tóth (izd.), Den Himmel offen halten. Ein Plädoyer für Kirchenentwicklung in Europa, Innsbruck, 2000., 31-38, 37. 
pak nije u ozdravljenju od raka, nego $u$ iskustvu da nisi prepušten samome sebi u teškim trenutcima. Dostojanstvo i cjelovitost, osobnost nisu vezane uz psihičko ili tjelesno zdravlje. Vjera je čovjekov milosni, to jest darovani odgovor na nezasluženu susretljivu pažnju Božju. Pri tome je ozdravljenje popratna glazba, dodatak u iscjeliteljskom odnosu s Bogom, a ne svrha samom sebi.

\section{SPOZNAJA SAMOGA SEBE - PRIHVAĆANJE SAMOGA SEBE - LJUBAV PREMA SAMOME SEBI I SLIKA BOGA KOJI LJUBI}

Vratimo se na početak, na pitanje zapažanja samoga sebe: Kako rezultati empirijskih istraživanja pridonose temi skrbi za samoga sebe, osobito s obzirom na značenje slike Boga koji je ljubav? Mislim da je ključni element međuodnos spoznaje samoga sebe, prihvaćanja samoga sebe i ljubavi prema samome sebi.

Analitičar C. G. Jung, koji se intenzivno bavio tamnim stranama čovjeka, smatra da je iskreno, bezuvjetno prihvaćanje samoga sebe, bez samozavaravanja, „najteža, pa i nemoguća stvar“26. Za Junga poteškoća nije u izvanjskim društvenim, možda normativnim, preprekama, nego, štoviše, u nutrini čovjeka. Potreban je nekakav oblik skrbi za samoga sebe koji ne podliježe napasti uljepšanih slika o samome sebi. Iskreno prihvaćanje samoga sebe može biti i bolno, te time predstavlja suprotnost egoizmu. C. G. Jung opisuje to koristeći se biblijskom slikom: „Što ako bih otkrio da je u samome meni najmanji od svih, nasiromašniji od svih prosjaka, najdrskiji od svih drznika, pa čak i neprijatelj, da je upravo meni potrebna milostinja moje blagosti, da sam ja sâm neprijatelj kojeg trebam ljubiti? Što ako je to tako?" 27

Jung smjera na unutarnje trikove i mehanizme idealizacije u svakom čovjeku. Dakako, danas se smanjio „izvanjski“ moralistički i normativni pritisak društva i Crkve. No umjesto toga imamo druge tendencije, naime društvene zahtjeve za učinkovitošću, prisilu za optimiranjem samoga sebe sve do iscrpljenja, trajni pritisak za prikazivanjem samoga sebe, čak i za insceniranjem samoga sebe u najsjajnijem svjetlu. Zahtjevi i postavljene norme nisu nestali, nego

26 Carl G. Jung, Über die Beziehung der Psychotherapie zur Seelsorge, C.G. Jung, Von Mensch und Gott. Ein Lesebuch (ausgewählt von Franz Alt ), Olten, 1989., 51-85, 64s.

27 Carl G. Jung, Über die Beziehung der Psychotherapie zur Seelsorge, C.G. Jung, Von Mensch und Gott. Ein Lesebuch (ausgewählt von Franz Alt ), Olten, 1989., 51-85, 65. 
su se samo izmijenili. Ostala je unutarnja prisila za idealiziranjem i opasnost potiskivanja ili čak omalovažavanja aspekata svoga ja. Idealiziranje svoga ja ne vodi samo u veću potrebu potiskivanja i samozavaravanja, nego i do unutarnje ukočenosti, do otvrdnuća. Stoga nam je uvijek iznova potrebna potvrda da smo bezuvjetno prihvaćeni, a ona će nas osloboditi od pritiska da budemo bolji nego što jesmo. Drugim riječima, iskreno, neuljepšano zapažanje i prihvaćanje samoga sebe uspjet će samo pred licem Boga koji je ljubav. Nitko to nije izrazio bolje i sažetije od Romana Guardinija:

„Sebe mogu istinski spoznati samo ako se uistinu prihvatim, a sebe uistinu mogu prihvatiti samo ako čisto spoznam sebe. Jedno pretpostavlja drugo.“

Nepristrano zapažanje samoga sebe s minimumom potiskivanja i samozavaravanja moguće je samo ako je na mene usmjeren pogled pun ljubavi. Samo u pogledu punom ljubavi može se i smije se zapaziti baš sve. Samo se iskrenim samozapažanjem koje ne bježi od vlastitih tamnih strana može iznjedriti i ostvariti ljubav prema samome sebi. Idealiziranoj slici samoga sebe nije potrebna ljubav prema samome sebi, nego samo netko tko će se diviti i „klanjati“ vlastitome ja.

Daljnja literatura za produbljivanje:

A. Antonovsky, Salutogenese. Zur Entmystifizierung der Gesundheit, Tübingen, 1997.

C. Dahlgrün, Christliche Spiritualität. Formen und Traditionen der Suche nach Gott, Berlin, 2009.

E. Frick/T. Roser (izd.), Spiritualität und Medizin - Gemeinsame Sorge für den kranken Menschen, Stuttgart, 2011.

J. L. Griffith, Religion hilft, Religion schadet. Wie der Glaube unsere Gesundheit beeinflusst, Darmstadt, 2013.

B. Grom, Wie gesund macht der Glaube? Stimmen der Zeit, (2011.) 2, 101-112.

A. von Heyl/K. Kemnitzer/K. Raschzok (izd.), Salutogenese im Raum der Kirche. Ein Handbuch, Leipzig, 2015.

R. Kunz/C. Kohli Reichenbacher (izd.), Spiritualität im Diskurs. Spiritualitätsforschung in theologischer Perspektive, Zürich, 2012.

A. Porterfield, Healing in the History of Christianity, New York, 2005.

T. Roser, Spiritual Care. Der Beitrag von Seelsorge zum Gesundheitswesen, ${ }^{2} 2017$.

C. Zwingmann/C. Klein/F. Jeserich (izd.): Religiosität: Die dunkle Seite. Beiträge zur empirischen Religionsforschung, Münster, 2017.

Prijevod s njemačkog jezika: Franjo Frankopan Velić 


\section{DOES RELIGION MAKE YOU HEALTHY? CONCLUSIONS FROM EMPIRICAL RELIGIOUS PSYCHOLOGY}

\section{Summary}

Self-care wants to perceive one's own needs and aims to maintain one's own physical and mental health. Whether religion and spirituality are sources of (mental) health and personal well-being or rather a risk, is highly controversially discussed. On the one hand individual experiences and on the other ideological trench warfare, shape the dispute. This paper sets the discussion on an "objective" basis by presenting evidence-based conclusions from various studies. So the rediscovery of the healing power of religion and spirituality becomes visible. Nevertheless, mindfulness is necessary and certain criteria are required so that religion can develop its healing power. But the evidence-based studies make visible: religiousness in different cases and psychical situations is not the same! We have to find out when, where and why religiousness has a constructive or destructive effect.

Keywords: religious psychology, mental health, resource, healthful factors, risk factors 